\title{
転移性骨腫瘍の臨床症状
}

\section{岡山大学医学部放射線医学教室（主任：青野 要教授）}

\section{佐藤 伸夫 -上田 裕之 - 中村 哲也 \\ 黒田 昌宏 - 神崎 典子・水田 昭文 \\ 村上 公則 ·上者 郁夫・橋本 啓二 \\ 平木 祥夫・青野 要}

(昭和62年 3 月 23 日受稿)

Key words : bone metastasis

clinical symptom

radiotherapy

\section{はじめに}

当院放射線科における過去 5 年間の入院患者 のうち, 癌の骨転移と診断された 33 症例につい て, 放射線治療（以下 RT と略）前後における 疼痛ならびに血清 $\mathrm{Ca}, \mathrm{LDH}$ および ALPの諸検 查値の変化について検討したので報告する.

\section{対}

象

对象は, 昭和 57 年 1 月より昭和 61 年 8 月まで の期間に，当科に入院していた患者のうち，骨 シンチグラフィ, 単純 $\mathrm{X}$ 線写真, $\mathrm{CT}$ 等の検査 にて，癌の骨転移と診断された 33 症例である。

\begin{tabular}{|c|c|c|c|c|}
\hline 原発巣 & 男 & 女 & 計 & $\%$ \\
\hline 肺 & 18 & 5 & 23 & 57.5 \\
\hline 乳 腺 & 0 & 4 & 4 & 10.0 \\
\hline 食 道 & 1 & 2 & 3 & 7.5 \\
\hline 大 腸 & 1 & 1 & 2 & 5.0 \\
\hline 腎 & 0 & 1 & 1 & 2.5 \\
\hline 膀 胱 & 1 & 0 & 1 & 2.5 \\
\hline 甲状腺 & 0 & 1 & 1 & 2.5 \\
\hline 肝 & 1 & 0 & 1 & 2.5 \\
\hline 皮 虞 & 1 & 0 & 1 & 2.5 \\
\hline 不，明 & 2 & 1 & 3 & 7.5 \\
\hline 計 & 25 & 15 & 40 & 100 \\
\hline
\end{tabular}

その内訳は，男性 25 例，女性 15 例で，年齢は， 35 寸から 82 才，平均 61 才である。原発巣は，肺 癌 23 例 $(57.5 \%)$ と最も多く, 乳癌 4 例 $(10 \%)$, 食道癌 3 例 $(7.5 \%)$ ，大腸癌 2 例 $(5 \%)$ ，腎癌，甲 状腺癌, 肝癌, 膀腅癌, 皮膚癌がそれぞれ 1 例, 原発巣不明の症例が 3 例である(表 1 )。このう ち，単発性の骨転移症例が12例，多発性のもの が27例であり, 多発性の症例が, 3 分の 2 以上 をしめている。

\section{結果}

骨転移部位は，替椎が最も多く, 28病変 $(36.7$ \%)で, 次いで助骨22病変 $(28.9 \%)$, 骨盤 13 病変
表 2 骨転移部位

\begin{tabular}{|c|c|c|c|}
\hline \multicolumn{2}{|c|}{ 部 位 } & 病変数 & $(\%)$ \\
\hline 頭 蓋 & 骨 & 2 & $(2.6)$ \\
\hline 頸 & 椎 & 5 & $(6.6)$ \\
\hline 胸 & 椎 & 14 & (18.5) \\
\hline 腰 & 椎 & 9 & (11.9) \\
\hline 胸 & 骨 & 2 & $(2.6)$ \\
\hline 肋 & 骨 & 22 & (28.9) \\
\hline 肩 甲 & 骨 & 1 & $(1.3)$ \\
\hline 鎖 & 骨 & 1 & (1.3) \\
\hline 上 腕 & 骨 & 4 & $(5.3)$ \\
\hline 骨 & 盤 & 13 & (17.1) \\
\hline 大 腿 & 骨 & 3 & ( 3.9$)$ \\
\hline 計 & & 76 & (100) \\
\hline
\end{tabular}


表 3 初発症状

\begin{tabular}{|c|c|c|}
\hline 初発症状 & 例数 & $\%$ \\
\hline 痛 & 30 & 75 \\
\hline 背部 痛 & 7 & 17.5 \\
\hline 胸䚛 & 4 & 10 \\
\hline 下肢 痛 & 4 & 10 \\
\hline 上肢痛 & 4 & 10 \\
\hline 腰痛 & 7 & 17.5 \\
\hline 頭 痛 & 2 & 5 \\
\hline 項 部 痛 & 2 & 5 \\
\hline 腫 脹 & 1 & 2.5 \\
\hline 無症 状 & 9 & 22.5 \\
\hline
\end{tabular}

表 4 疼痛，血清 Ca, ALP, LDH

（症例数）

疼 痛 血清Ca上昇 ALP 上昇 $\mathrm{LDH}$ 上昇

\begin{tabular}{lcccc}
\hline 全症例 数 & 35 & 5 & 13 & 9 \\
旰転移の認 & & & & 9 \\
められなか & $(12.5 \%)$ & $(32.5 \%)$ & $(22.5 \%)$ \\
つた症例数 & - & 1 & 9 & 5 \\
\hline
\end{tabular}

表 5 RTによる疼痛, 血清Ca, ALP,LDH の変化

(症例数)

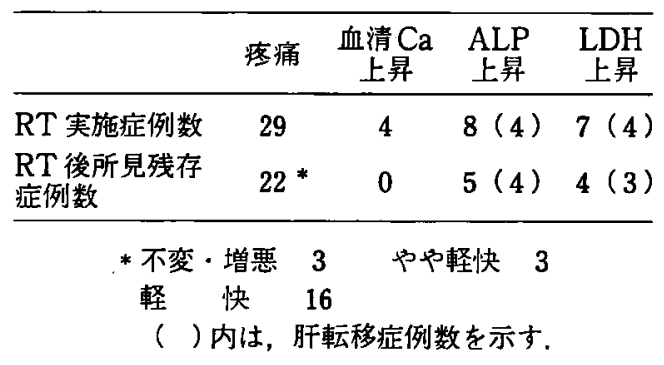

(17.1\%)，上腕骨 4 病変 $(5.3 \%)$ である（表 2$).$

初発症状は，疼痛が 30 例で75\%を占めている. 部位としては，背部痛が 7例 (17 5\%) 腰痛が 7 例 $(17.5 \%)$ 胸痛が 4 例 (10\%) となっている. 他 に右側胸部の腫脹を初発症状としたものが 1 例 (3.3\%)，無症状が 9例 (22.5\%) あった（表 3).

臨床症状では，疼痛が全症例中 35 例 (87.5\%) に認められたが，疼痛の他にも頸觬の圧迫によ る四肢麻疩, 四肢の運動障害, 知賞障害も認め られた．血清生化学的検査においては，ALPの 上昇がみられたものが13例 (32.5\%)，LDHの上 昇がみられたものが 9 例 (22.5\%)，血清 $\mathrm{Ca}$ 值の 上昇がみられたものが5例（12.5\%）にみられた。
しかし，肝転移の認められた症例数を除くとALP の上昇は 9 例にみられ $\mathrm{LDH} の$ 上昇したものは $\mathbf{5}$ 例となった (表 4 ).

また，疼痛やこれらの㟟常值の RT による変 化については，疼痛の全く消失したものが7例 (24.1\%)であり，やゃ疼痛の軽快したものも含 めると 26 例 (89.6\%) に何らかの改善が認められ ている，血清生化学的検查についてもALP 上昇 例のうち 3 例, $\mathrm{LDH}$ 上昇例のうち 4 例, 血清 $\mathrm{Ca}$ 值上昇例のうち 4 例が, 治療により正常範囲 内に回復した（表 5 ).

$$
\text { 症例 }
$$

症例 1 は, 62 才男性, 主訴は嗄声及び右側胸 部痛である. 昭和58年 8 月頃より嗄声が出現し， 精査の結果肺癌の診断をうけ， MMC 等による化 学療法行うも効果なく, 胸痛も出現したため, RT 目的にて当科入院となった. RT としては右第 5 肪骨に ${ }^{60} \mathrm{Co} に て$ 前方より $4 \times 3 \mathrm{~cm}$ の照射野で 1 回 $2 \mathrm{~Gy}$ 週 5 回計 $40 \mathrm{~Gy}$ の照射を施行した．胸 痛は $10 \mathrm{~Gy}$ 照射時より軽快し， $18 \mathrm{~Gy}$ 照射後消 失した。また ALP が当初109 IU $/ 1$ とやや異常を 示していたが，RTにより正常範囲に回復した。

症例 2 は, 57 才女性, 主訴は背部痛であった。 右乳癌の診断にて, 昭和 53 年 2 月右乳房切断術 を施行したが，昭和 58 年 2 月頃より背部痛出現 し，5FU 等による化学療法を行った後，昭和 59 年 9 月 RT 目的にて当科入院となった．RT と しては，第 $5 ， 6 ， 7$ 胸椎には5.5 $\times 4 \mathrm{~cm}$ の照射 野で，第4腰椎には5.5×4 cm の照射野でLinac X 線 $10 \mathrm{MeV}$ 後方より各々 1 回 $2 \mathrm{~Gy}$ 週5回計 $40 \mathrm{~Gy}$ 照 射. また, 右第 6,7 肋骨に電子線 $10 \mathrm{MeV}$ 後方 より $10 \times 6 \mathrm{~cm}$ の照射野にて 1 回 $2 \mathrm{~Gy}$ 週 5 回計 $40 \mathrm{~Gy}$ 照射した。背部痛は $10 \mathrm{~Gy}$ で激痛が改善 し，20 Gy までは徐々に疼痛軽減がみられたが 消失にはいたらなかった，症例 1 と同样 ALP が $118 \mathrm{IU} / 1$ とやや高值であったが，RTにより正常 範囲内に回復した。

\section{考察}

骨転移部位としては，背椎が最多であり，な かでも腰椎に多いといわれているが1,4)。当科に おいて今回は，胸椎が最も多くなっている，し 
かし，その他は，肋骨，骨盤，上腕骨となって おり, 従来の報告と同様な傾向を示していると 考えられる.

初発症状として疼痛が75\%と最も多いのも， 従来の報告の通りであるが1.6)，その部位として， 背部痛, 腰痛, 胸痛が多いのは, 転移部位が, 脊椎，肋骨に多いことによると考えられる。 ま た，初発症状が無症状であったものが 9 例ある が,このうち 4 例には，経過中に疼痛が出現し ており, 臨床症状が出現してくる以前に骨シン チグラフィや骨 X 線写真によって骨転移が発 見されたものと考えられる．他の症例において は, 疼痛等がみられなかったが, 全経過を通し て疼痛のない場合もあるため ${ }^{2)}$ ，これに相当す るものと思われる.

生化学的検查では，ALPについては約 $50 \%$ の症例に上昇が認められたとの報告がある31. 今回対象とした症例の場合, $32.5 \%$ に上昇がみ られた.しかし, 肝転移の認められた症例を除 くと上昇は， $22.5 \%$ にられたのみであり，そ

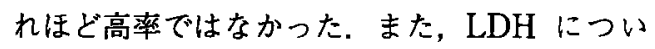
ても71.8\%に上昇がみられ，その值は腫瘍の大 きさに比例するとの報告もあるが4), 我々の検 討した症例では，9例 $(22.5 \%)$ に上昇がみられ， 肝転移を認めた症例を除くと，5例 (12.5\%)に 上昇を認めたに過ぎなかった. 血清 $\mathrm{Ca}$ 值の変 動については，一般に原発性骨腫瘍では変動が ほとんどみられず，広範囲の癌の骨転移，特に 乳癌, 肺癌, 腎癌などからの骨転移のときに高 カルシウム血症がみられることがあると言われ ており，8-9\%に上昇が認められたとの報告 もある4). 今回対象とした症例でも，9.1\%に血
清 Ca 值の上昇が認められておりここれら全例 に広範囲の骨転移が認められほぼ同様の結果で あった。

次に, 疼痛やこれら生化学検查の異常値の放 射線治療による変化については, 今回検討を行 った29症例のうち疼痛の消失したものは7例 (24.1 \%)，何らかの改善を示したものを含めると26例 (89.6\%)となっており，諸家の報告1 3,5.6) とほ ほ同様の結果と思われる. ALP 上昇例のうちの 3 例， LDH 上昇例のうちの4例が，それぞれ放 射線治療後正常值に回復しており，両者ともに 上昇例のうちの約 3 分の 1 を占めている. ALP については治療後, 再上昇を示したとの報告も あるが3，今回はそのような傾向は認められな かったようである．血清 $\mathrm{Ca}$ 值の放射線治療に よる変動についての報告は少ないが, 今回の上 昇例 3 例の全例において正常值に回復した. し かし，いずれの検查值も高率に変動していると はいえず，上昇も高度ではないものが多いこと もあり, 治療の効果判定の基準としては疼痛や 画像診断に比べて劣ると思われる.

$$
\text { まとめ }
$$

当科における過去 5 年間の入院患者のうち骨 転移之診断された 40 症例について放射線治療に よる疼痛や諸検查値の変化について報告した. 疼痛は29例中26例 $(89.6 \%)$ に改善が認められた が, ALP, LDH は上昇例も少なく，また治療 により改善したと思われる症例も 3 分の 1 程度 であった，血清 Ca 值は，広沉な骨転移を示し た 5 症例で上昇がみられたが，治療によりこの うち 4 例が正常值に回復した.

\section{文献}

1. 福間久俊：転移性骨腫瘍. 整形外科 MOOK (1983) 26，208-215.

2. 佐藤三郎：がんの骨転移の診断に関する研究. 医学研究 (1966) 36, 487-519.

3. 後藤 将：がんの骨転移の臨床経過. 福岡医学雑誌 (1966) 57, 883-908.

4. 北川敏夫, 高木克公, 原田正孝：骨腫瘍の臨床所見. 整形外科 MOOK (1983) 26, $1-4$.

5. 藤井正敏, 北川俊夫：骨転移の放射線治療. 滛の臨床 (1973) 19，1003-1007.

6. 菅原 正, 中間昌博：骨転移巣の放射線治療. 臨床放射線 (1979) 24，931-935. 


\section{A Clinical Study of Bone Metastasis in Carcinoma}

Nobuo SaTOH, Hiroyuki UEDA, Tetsuya NaKamura, Masahiro KURodA, Noriko KanZaKI, Akihumi MIZUTA, Kiminori MURAKami, Ikuo JoJa, Keiji Hashimoto, Yoshio HIRAKI and Kaname AONO

Department of Radiology, Okayama University Medical School

The study included 40 cases of bone metastasis experienced from January 1982 to August 1986 at the Department of Radiology, Okayama University Hospital. The rate of pain Remission was $89.6 \%$ in 29 patients given radiotherapy. Increases in serum ALP and LDH were found in a few patients and a quarter of these patients improved after radiotherapy. Serum Ca increased in 5 patients with multiple bone metastases. 